\title{
STRATEGIC ENVIRONMENTAL ASSESSMENT FOR METROPOLITAN PLANS OF COASTAL AREAS. THE CASE OF VALENCIA
}

\author{
JOSÉ LUIS MIRALLES I GARCIA \\ Department of Urban Planning, Polytechnic University of Valencia (Spain).
}

\begin{abstract}
Many uses of land, such as for building and all kinds of infrastructure, are concentrated in the metropolitan areas of coastal cities. Often, urban and infrastructure uses are dispersed across the territory, generating situations of urban sprawl. In addition, especially in coastal areas, new urban expansion and new infrastructures are in conflict with other uses, such as for agrological areas, beaches or natural areas. In general, the best agricultural zones on the Mediterranean coast are next to the sea. The more important touristic areas are also next to the sea. Therefore, contradictions between sustainability and development are very intense. All these conditions take place in the metropolitan area of Valencia. Now, regional government wants to develop a metropolitan plan to generate an equilibrium between the different uses and to reserve areas for new urban use and infrastructure. In reality, the area's population is now stable but, for economic activities to be competitive, new usage is required as logistic areas or to increase the rail network. A global vision is also needed for urban transport in the metropolitan area. On the other hand, the environmental impacts of current and planned uses can be significant. Moreover, the perception of environmental impacts has changed over time. It is necessary to preserve areas, such as agricultural areas or natural areas, but it is also necessary to produce the quality of landscape perceived by visitors or to generate a green infrastructure network, according to European policy. Finally, we must integrate all these elements with current and new urban and civil infrastructure uses through a public decision-making process. The objective of this paper is to introduce a methodology to integrate the process of public environmental assessment on the works to elaborate a metropolitan plan for a coastal city such as Valencia (Spain) next to the Mediterranean Sea.
\end{abstract}

Keywords: green infrastructure, landscape and urban planning; regional planning, strategic environmental assessment.

\section{INTRODUCTION}

In the 21st century in particular, and during the urban expansion period of 1997 to 2007 and the period of the real estate crisis from 2008 to the present, metropolitan areas have increased in surface area and decreased in density. According to Wheeler [1], who studied the dynamics of six metropolitan regions of the US in the period 1980-2005, the dynamics were characterized by:

- A very large increase in their urbanized areas and a very large increase in the surface of metropolitan areas.

- An important decrease in density, of both population and houses, in metropolitan regions.

In Spain, between 1997 and 2007, there was an expansive economic cycle based on real estate speculation that ended with the economic crisis, which began in 2008 and still continues today [2], with special consequences for touristic coastal zones [3].

Feria and Martínez [4] studied the dynamics of metropolitan areas of Spain between 2001 and 2011. They observed that, in the case of Spain, metropolitan areas increased their populations during the period of the real estate bubble, as you can see in Table 1, but, in the crisis period, their population stopped or decreased. They think that this trend will continue. Nevertheless, the process of metropolitan area expansion and urban sprawl persists and densities 
Table 1: Population evolution of metropolitan areas of Spain. Source: Feria and Martínez [4].

\begin{tabular}{lllll}
\hline & 2001 & & 2011 \\
\hline Metropolitan area & Municipalities & Population & Municipalities & Population \\
\hline Madrid & 172 & $5,623,784$ & 172 & $6,729,769$ \\
Barcelona & 130 & $4,340,618$ & 139 & $5,088,201$ \\
Valencia & 74 & $1,594,762$ & 80 & $1,935,363$ \\
Sevilla & 49 & $1,369,708$ & 51 & $1,581,798$ \\
Málaga-Marbella & 29 & $1,000,900$ & 25 & $1,239,954$ \\
\hline
\end{tabular}

continue decreasing. That is the case of the metropolitan area of Valencia, a metropolitan area next to the Mediterranean Sea.

Therefore, it is necessary to understand the new reality of metropolitan areas in order to generate policies to improve sustainability in the metropolitan territory through a new kind of planning [5]. In this situation, it is essential that environmental issues are part of the process of strategic environmental assessment.

In the metropolitan area of Valencia, different borders can be identified in function of different criteria. According to the Valencian Community's Territorial Strategy [6], that stablishes different criteria that Feria, the functional area of Valencia covers an area of $3897 \mathrm{~km}^{2}$ with a population of $1,774,550$ inhabitants in 2015 . The area includes 90 municipalities. Figure 1 shows the surface occupied by the metropolitan area, according a study

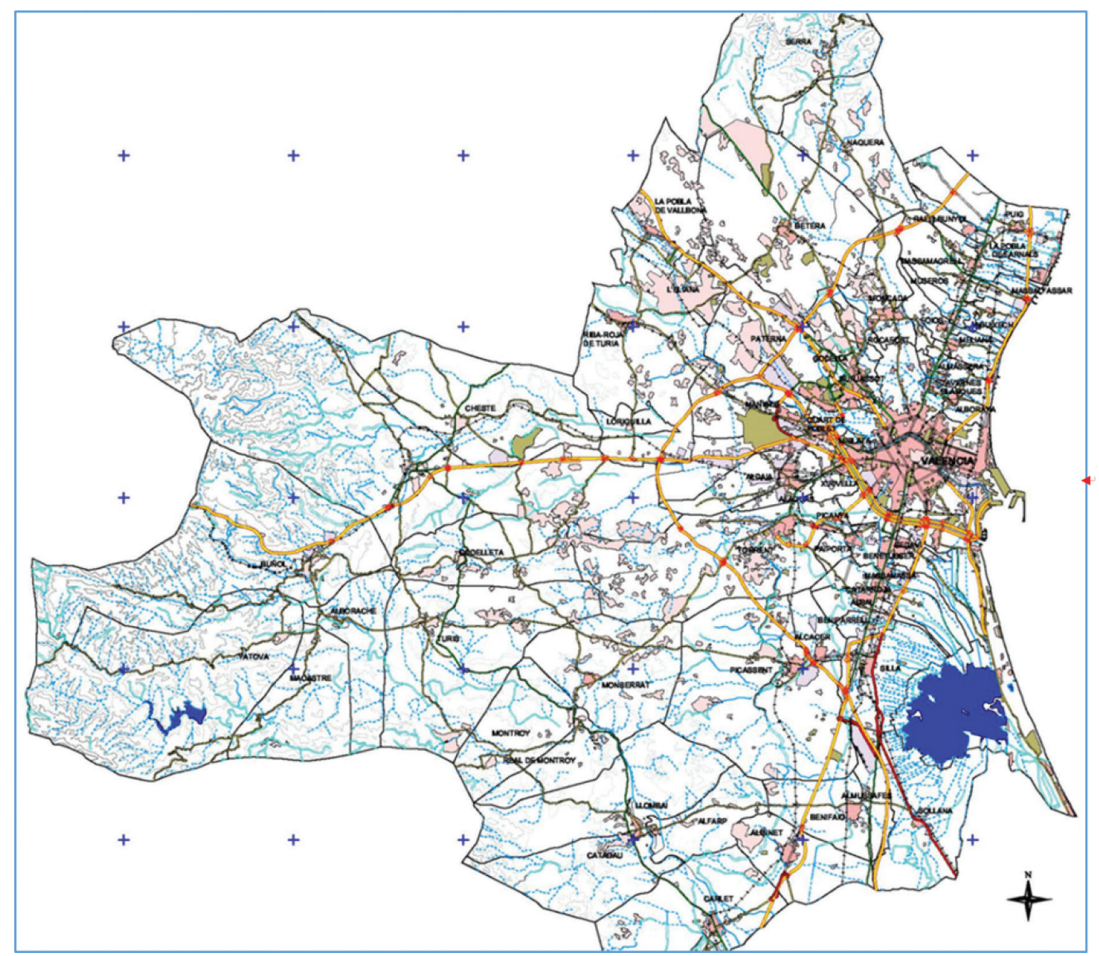

Figure 1: Metropolitan area of Valencia. Source: UDR F. Eiximenis. 
realized by the author's research team, UDR F. Eiximenis, in 2003. The current surface of the metropolitan area is very similar to that of 2003.

In 2005, the population of this area was $1,740,335$ inhabitants, increasing to $1,807,826$ in 2015, according to the data of the Initial Document for Strategic Environmental Assessment or the Draft Plan of the Metropolitan Plan of Valencia [7]. In addition, there are 895 ha of urbanized land, with the capacity for 22,375 new homes, and 1280 ha of commercial and industrial urbanized lands, with the capacity for 51,200 new employees.

Therefore, the metropolitan area underwent a moderate increase between 2005 and 2015. However, as shown in Table 2, the artificial surface has undergone a large increase, according to Boira [8].

In addition, there is an important amount of land prepared for urban development, as shown in Table 3. With an average density of 25 homes/ha, land planned for residential developments in urban plans (urbanizable lands) has the capacity for about 150,000 new homes or 375,000 inhabitants. On the other hand, land for economic activities, with a ratio of 40 employees/ha, has the capacity for about 138,000 new employees.

All this means that, although population is not growing very much, urban use is increasing in a very intensive way. Urban expansion in the metropolitan area of Valencia has taken place in the form of urban sprawl, as can be seen in Fig. 1. This involves an increase in the cost of municipal public services $[9,10]$. In addition, this intensive process of urban expansion and sprawl produces important environmental impacts.

\section{CONFLICTS BETWEEN USES IN THE COASTAL AREA OF VALENCIA}

The coastal area of Valencia, as in the case of many coastal areas, is very complex. Many uses are in clear competition with each other and, thus, generate conflict. In the following points, the most important uses are analysed in a synthetic form.

\subsection{Agricultural land}

Valencia is located in the centre of a large expansion of high-quality agricultural land: the Horta of Valencia [11]. The climate of the Mediterranean coast of Spain is hot and dry. With

Table 2: Population evolution and artificial land (technical terminology of the CORINE database) of Valencia Urban Region (1990-2006). Source: Boira [8].

\begin{tabular}{llrr}
\hline Artificial land (ha) & 1990 & 2000 & \multicolumn{1}{c}{2006} \\
\hline Valencian Community & $73,335.28$ & $109,612.90$ & $125,794.52$ \\
Valencia Urban Region & $28,116.76$ & $36,363.74$ & $41,766.75$ \\
\hline
\end{tabular}

Table 3: Land for urban development. Source: GVA [7].

\begin{tabular}{lc}
\hline Urbanizable land & Surface (ha) \\
\hline Residential & 6138.86 \\
Public facilities & 1987.26 \\
Economic activities & 4464.07 \\
$\quad$ - Industrial & 3468.74 \\
$\quad$ Tertiary & 995.33 \\
Total & $12,590.19$ \\
\hline
\end{tabular}


this climate, if water is available for irrigation and the soil is suitable, coastal plains develop highly productive agriculture. That has been the case in Valencia for a long time. Agricultural activity is historical, and the medieval institution of the Water Court, declared a UNESCO World Heritage site, resolves problems between farmers: in general, problems about water management and irrigation. The surface of the irrigation zones has historically been extensive, covering about 23,000 ha. Nevertheless, until now, about 13,000 ha of irrigation zones have been transformed by an irreversible process of Valencia' urban expansion and the surrounding municipalities. The rest is now in the process of being protected, along with other nearby irrigated areas.

\subsection{Albufera lake}

On the south coast of Valencia, there is the Albufera Natural Park of Valencia. Most of this area has been protected since 1986 [12]. In the geographical area of the park, several activities coexist:

- A wetland ecosystem of international level that is a resting place for birds migrating from Europe to Africa.

- An area especially capable of cultivating rice around the lake; this involves specific management of both water and the water levels of the lake.

- Tourist activity, in general in the whole area and in particular along the coast.

\subsection{Tourist activities}

Tourist activity is very intense along the entire Spanish Mediterranean coast. This activity is particularly important in Valencia [13]. In the metropolitan area, tourist activity is located in Valencia City in the form of urban tourism, on the north coast and, finally, on the south coast, inside the Natural Park of Albufera. Urban tourist development can produce important environmental impacts [14], a consequence of which is the degradation of the tourist activity itself. The motorway and roads that provide access to the tourist beaches located in the park form a hard barrier for the ecosystem and produce high mortality among the fauna.

\subsection{Seaport activity}

The seaport of Valencia is one of the most important on the Mediterranean Sea [15]. It was the busiest Mediterranean seaport for container traffic in 2015. The port needs specific facilities located inland for managing freight, especially road and rail infrastructure to provide access to the port and its logistic areas. These demands condition the planning of the metropolitan territory. There are physical limits to the extension of the port: to the north lies Valencia's beach and to the south, the Natural Park of Albufera.

\subsection{Land that is urbanized land but not built on}

During the period of the real estate boom, a great deal of land was developed but not built on. In the metropolitan area of Valencia, there are 895 ha of residential land, with the entire infrastructure completed but without buildings, having the capacity for 22,375 new houses; there 
are also 1280 ha of commercial and industrial land with the capacity for 51,200 new employees [16]. So, the capacity for new houses and economic activity is very high.

\subsection{Land planned for urban development (urbanizable land)}

On the other hand, and in addition to the above figures, the municipalities of the metropolitan area have currently planned 22,637 ha of urban land (land already built) and 12,509 ha of land for urban development (urbanizable land) [16]. Land for urban development has the following destiny: 6138 ha are residential land with the capacity for about 150,000 new houses with an average ratio of 25 houses/ha; 3468 ha of land are for economic activity, commercial and industrial, with the capacity for about 138,000 new employees with a ratio of 40 employees/ha. Obviously, a great amount of this land planned for urban development is completely unnecessary.

\subsection{The mediterranean corridor}

The Mediterranean Corridor is a strategic project to connect the whole EU through transport infrastructure, for freight and passengers, from the south to the north. This corridor has been promoted by the FERRMED lobby [17] since 2004. The corridor runs along the entire Spanish Mediterranean coast and therefore goes through Valencia to connect to the seaport. Consequently, it is necessary to plan the infrastructure to support the servicing of this corridor in the future.

\subsection{Land demanded for new uses (logistic areas)}

Due to the global expansion of economic activities, logistics have become very important. Transport logistics demand large spaces for the transfer of goods between different transportation modes and also for their storage and distribution. It is necessary to plan these spaces in adequate locations.

\section{REGARDING THE SUSTAINABILITY OF THE TERRITORY}

Environmental impacts produced by urban usage in the territory may be caused by two possible processes:

- land transformation from rural usage to urban or artificial usage

- economic and social activities (residential, commercial, industrial, transport...)

The main characteristic of urban or artificial usage taking place in the territory is irreversibility. So, when rural land is transformed into urban or artificial land, the possibility of reversing the action is extremely low and, usually, very expensive. As a result, in fact, it is impossible to reverse the destruction of rural usage when it is transformed into urban usage.

On the contrary, economic and social activities produce environmental impacts that, in general, can be corrected or reversed by the appropriate technology.

Thus, from the point of view of regional planning, to achieve sustainability, society must achieve a distribution of land usage to keep natural resources that produce the goods and services necessary for social and economic activities and not destroy them by irreversibly transforming these rural uses into urban usage. These natural resources are the so-called Natural Capital. 
According to the well-known theory of the ecological footprint and the Living Planet Report, published by the World Wildlife Fund every 2 years [18], social and economic activities consume the natural resources produced by a certain surface of the planet and produce pollutants that are absorbed by a certain surface of ecosystems. The total surface is the ecological footprint. Now then, it is possible to consider the same concept from another point of view. It is possible to consider that the surface of the ecological footprint is also the surface needed for society to maintain its level of social and economic activity. In this sense, the ecological footprint is also the ecological larder. If we want to maintain social and economic activities, we must maintain the surfaces that produce the environmental goods and services necessaries for activities of society, that is, the ecological larder or Natural Capital. Not all territory produces environmental goods and services nor the same intensity. The vulnerability of a certain zone against a concrete urban use (such as general urban use, facilities or industries) measures the destruction of Natural Capital if that use is located in that zone.

On the other hand, to consider the sustainability of uses in the territory, it is also necessary to consider the economic costs necessary to build safely against risks. In this case, the problem is not the destruction of environmental values but the destruction of buildings if they are built in these zones, or the construction costs. The capability of a certain zone of territory for a concrete urban use (such as general urban uses, facilities or industries) refers to its suitable conditions for building safely without excessive costs.

From the two previous points of view, for the conservation of Natural Capital and for safety, a third option can be added: the green infrastructure. The green infrastructure adds the idea of a network.

The European Commission [19] defines Green Infrastructure (GI) - Enhancing Europe's Natural Capital, as a strategically planned network of natural and semi-natural areas with other environmental features designed and managed to deliver a wide range of ecosystem services. It incorporates green spaces (or blue if aquatic ecosystems are concerned) and other physical features in terrestrial (including coastal) and marine areas. On land, GI is present in rural and urban settings.

In fact, green infrastructure produces a system of interconnected open spaces and, consequently, ecosystems are not isolated. This implies the necessity to identify the connections of areas between open spaces and to plan them as undevelopable land.

And finally, it is still possible to consider another point of view: that of the landscape. People look at the territory and have a view of the landscape. This view is important because people often value the territory according to the landscape. It is possible to design the landscape based on the three perspectives previously mentioned. In this sense, the landscape will be an integration of all the territory's sustainability points of view.

\section{OBJECTIVES}

The author's research team, UDR F. Eiximenis of Universitat Politècnica de València (Spain), developed in 1996 a method for the evaluation of the aptitude of the territory for urban uses, named the Method of Aptitude for Sustainable Urban Development (hereafter, method ASUD).

The research team is now working to update the method [20]. The objective of this article is to show a proposal for the planning of metropolitan coastal areas in order to optimize the territorial environment in the Strategic Environmental Assessment process developed for the case of Valencia. 


\section{PLANNING METROPOLITAN COASTAL AREAS TO OPTIMIZE THE ENVIRONMENT IN THE PROCESS OF STRATEGIC ENVIRONMENTAL ASSESSMENT}

In the European Union, the Strategic Environmental Assessment (SEA) is a public participation process in decision-making about the environmental consequences of programmes and plans [21]. The general SEA procedure, after the screening process, is as follows:

The SEA procedure can be summarized as follows: an environmental report is prepared in which the likely significant effects on the environment and the reasonable alternatives of the proposed plan or programme are identified. The public and the environmental authorities are informed and consulted on the draft plan or programme and the environmental report prepared.

The environmental report and the results of the consultations are taken into account before adoption. Once the plan or programme is adopted, the environmental authorities and the public are informed and relevant information is made available to them. In order to identify unforeseen adverse effects at an early stage, significant environmental effects of the plan or programme are to be monitored.

According to Valencian laws, the process has the following phases:

- Declaration of the start process for the elaboration of a plan or programme

- Elaboration of the initial document of the plan or programme or draft plan/programme

- Elaboration of the plan/programme

- Elaboration of the environmental report of the plan/programme

- Public participation in decision-making

- Analysis of public participation process, modification of the plan or programme, if necessary, according to suggestions, and response to stakeholders

- Elaboration of the final document of the plan/programme

- Elaboration of the Environmental Declaration

- Communication and public exposition of final documents.

In this process, the Environmental Report must focus on the likely significant effects on the environment produced by the plan. Depending on the type of plan, the significant environmental effects will be one or the other.

In the case of territorial plans, most of the significant environmental effects are produced by the transformation of rural to urban land usage. The Method of Aptitude for Sustainable Urban Development (ASUD) allows the identification of rural lands that must not be transformed into urban or artificial land, from a sustainable point of view.

This method allows the measurement of the aptitude of each homogeneous zone for different urban uses, depending on the zone's capability for and vulnerability to different uses. In Valencia, capability is a function of the variables that can condition or determine the location of the use in the zone: slope, soil resistance, flood risk, landslide risk. For all variables, the homogeneous zones are classified into three groups:

A. Zones that do not present limitations for urban use, according to the variable considered.

B. Zones that present limitations for urban use, according to this variable, but can be corrected at reasonable cost.

C. Zones that present strong limitations for urban use, according to this variable; the problem cannot be corrected or its correction is too expensive. 
These situations can be mapped for each variable. If different maps are overlapped, the result will be an integrated map of capability with all situations A, B or C.

On the other hand, vulnerability is a function of environmental variables that can be impacted if the urban or artificial use is located in the zone: agricultural lands, forest, vulnerability of aquifer and protected areas. In fact, all those variables are part of the Natural Capital. Also, for all variables, the homogeneous zones are classified into three groups:

A. Zones that are not part of the Natural Capital.

B. Zones in which some environmental variable can be impacted, but the impact can be corrected at reasonable cost.

C. Zones in which the transformation to urban land implies the irreversible destruction of the Natural Capital.

These situations can also be mapped for each variable. If different maps are overlapped, the result will be an integrated map of vulnerability variables with all situations $\mathrm{A}, \mathrm{B}$ or $\mathrm{C}$.

The final aptitude of each zone for each urban use will be obtained by overlapping the capability and vulnerability maps for each urban use. This final map identifies the zones that must be preserved from urban development. That is, a map of open spaces or a map of a system of open spaces with different functions, such as an ecological larder or safety. All this analysis is performed by using Geographical Information System (GIS).

This map will be completed by functional and ecological corridors which also must be part of green infrastructure. The main hydrological network is a good lineal space, free of urbanization, to connect the open spaces between that.

It is also possible to use algorithms to identify better points to connect open spaces. For example, it is possible to calculate an 'index of permeability' of points of the territory, based on land use, orography and distance to roads. When a zone has a natural or similar use, the slope is medium or high and the distance to roads is high, the theoretical permeability for the connection of zones is higher. According to these variables, it is possible to create numerical criteria about the degree of compliance of each variable and, in consequence, the theoretical grade of connection between the different zones. Of course, these resulting zones must be contrasted with real experience. These must be protected and added to the protected areas and open spaces to generate a network.

Finally, it will be necessary to integrate the perception of the landscape by the consideration of two issues:

- Identification of landmarks and scenic views (elements observed).

- Identification of viewpoints and scenic ways (observation points).

These perceptions must be considered in order to protect the views.

The integration of all concepts will produce a complete green infrastructure. All integrated analyses are performed by the use of GIS. This green infrastructure will be the basis for protecting the territory from new urban and artificial usage. Of course, these new uses or the renovation of old uses will create new landscapes.

\section{CONCLUSIONS}

Sustainability is a general and complex concept. Therefore, it is possible to study the sustainability for different elements or activities. Particularly, it is possible to apply the concept to 
the territory. In fact, all human activities are produced in the territory. The study of territory always requires a geographical vision. Historically, the society have used the territory like object to extract profit. However, at present the territory is very artificial or urbanized, especially in metropolitan areas, and often makes degraded landscapes. On the other hand, the expansion of urbanized lands and the stop of population' growth forces to act on urbanized land to implement new urban uses and to avoid more expansion of urban sprawl. Accordingly, it is necessary the application of a new territorial quality concept in planning processes and Strategic Environmental Assessment.

Green infrastructure is a very useful concept. In current metropolitan areas situation, green infrastructure must be considered prior to metropolitan planning of urban and artificial uses in order to maintain historical landscapes but also to make new quality landscapes.

As a result of research, Green infrastructure can be determined as the integration of the land's aptitude for different urban and artificial uses (capability + vulnerability), functional and ecological corridors and landscape-views (elements observed + observation points). Note you that vulnerability concept includes the Natural Capital to preserve for the future. Therefore, this key aspect is integrated in the methodology.

The whole analysis is essentially geographic. Because of this, the use of Geographic Information Systems is especially indicated as operational instruments.

Determination of the green infrastructure is an objective process to apply sustainability concept on land transformation from rural into urban and artificial usage through regional planning.

This process of determining the green infrastructure allows the creation of an alternative to the territorial model with sustainability criteria in the Strategic Environmental Assessment process.

Finally, as it is known, regional planning have as objectives, among others, maintain natural resources (as a part of green infrastructure) and design new urban uses in zones already urbanized or not. Well, the concept of green infrastructure also allows to design new landscapes specially in border areas between new urban and artificial uses and natural areas or when green infrastructures crosses urban areas.

\section{REFERENCES}

[1] Wheeler, S.M., The evolution of built landscapes in metropolitan regions. Journal of Planning Education and Research, SAGE Publications: New Jersey, 27, pp. 400-416, 2008. available at www.//jpe.sagepub.com/cgi/content/abstract/27/4/400 (accessed 20 February 2017).

[2] Miralles i Garcia, J.L., El darrer cicle immobiliari al País Valencià. O el progrés de la misèria. Fundació Nexe: València, 2014.

[3] García-Ayllón, S., Retrospective analysis of urban development in the Spanish Mediterranean Coast. WIT Transactions on Ecology and the Environment, WIT Press: Southampton, 179, pp. 291-302, 2013.

[4] Feria Toribio, J.M. \& Martínez Bernabeu, L., La definición y delimitación del sistema metropolitano español: permanencias y cambios entre 2001 y 2011. Revista Ciudad y Territorio. Estudios Territoriales, Ministerio de Fomento: Madrid, 187, pp. 9-24, 2016.

[5] Miralles i Garcia, J.L., Revising the basis for planning a new kind of progress: the case of Valencia's city. WIT Transactions on The Built Environment, WIT Press: Southampton, 148, pp. 3-14, 2015. 
[6] Generalitat Valenciana (GVA)., Conselleria d'Habitatge, Obres Públiques i Vertebració del Territori. Estrategia Territorial de la Comunitat Valenciana. Website, Valencia, available at http://www.habitatge.gva.es/web/planificacion-territorial-e-infraestructura-verde/estrategia-territorial-de-la-comunitat-valenciana-77496 (accessed 20 February 2017).

[7] Generalitat Valenciana (GVA)., Conselleria d'Habitatge, Obres Públiques i Vertebració del Territori. Documento de Inicio del proceso de Evaluación Ambiental y Territorial Estratégica del Plan de Acción Territorial Metropolitano de Valencia. Website, Valencia, available at http://www.habitatge.gva.es/web/planificacion-territorial-e-infraestructura-verde/plan-de-accion-territorial-metropolitano-de-valencia-pateval- (accessed 20 February 2017).

[8] Boira, J.V., Urbanismo expansivo: de la utopía a la realidad. Proceedings of XXII Congreso de Geógrafos Españoles, pp. 79-90, 2011.

[9] Gielen, E., Costes del "Urban Sprawl" para la administración local. Publicacions de la Universitat de València: València, 2016.

[10] Gielen, E., Riutort-Mayol, G., Palencia-Jiménez, J.S. \& Cantarino, I., An urban sprawl index based on multivariate and Bayesian factor analysis with application at the municipality level in Valencia. Environment and Planning B: Analytics and City Science, 2017.

[11] Miralles i Garcia, J.L., Environmental management of peri-urban natural resources: L'Horta de València case study. WIT Transactions on Ecology and the Environment, WIT Press: Southampton, 192, pp. 99-110, 2015.

[12] www.albufera.com (accessed 20 February 2017).

[13] Miralles i García, J.L., Green infrastructure in Mediterranean Valencian Coast. International Journal of Sustainable Development and Planning (Online), 3(11), pp. 227-235, 2016.

[14] Miralles i García, J.L., Díaz Aguirre, S. \& Altur Grau, V.J., Environmental impact on the Mediterranean Spanish coast produced by the latest process of urban developments. WIT Transactions on Ecology and the Environment (Online), 155, pp. 379-389, 2012.

[15] www.valenciaport.com (accessed 20 February 2017).

[16] Generalitat Valenciana (GVA)., Conselleria d'Habitatge, Obres Públiques i Vertebració del Territori. Documento de Inicio del proceso de Evaluación Ambiental y Territorial Estratégica del Plan de Acción Territorial Metropolitano de Valencia. Website, Valencia, available at http://www.habitatge.gva.es/web/planificacion-territorial-e-infraestructura-verde/plan-de-accion-territorial-metropolitano-de-valencia-pateval- (accessed 20 February 2017).

[17] www.ferrmed.com (accessed 20 February 2017).

[18] World Wildlife Fund. Living Planet Report 2016., available at http://wwf.panda.org/ about_our_earth/all_publications/lpr_2016/ (accessed 20 February 2017).

[19] European Commission. Communication from the Commission to the European Parliament, the Council, the European Economic and Social Committee and the Committee of the Regions. Green Infrastructure (GI) - Enhancing Europe's Natural Capital. available at http://eur-lex. europa.eu/legal-content/EN/TXT/?uri=CELEX:52013DC0249 (accessed 20 February 2017).

[20] Miralles i García, J.L. \& Altur Grau, V.J., Updated method of aptitude to sustainable urban development for including green infrastructure. International Journal of Sustainable Development and Planning (Online), 6(11), pp. 970-979, 2016.

[21] European Commission., available at http://ec.europa.eu/environment/eia/sea-support. htm (accessed 20 February 2017). 